\title{
PENDAMPINGAN SATGAS COVID-19 YAYASAN MAHA BHOGA MARGA UNTUK MENINGKATKAN KESADARAN JEMAAT GKPB TERHADAP PELAPORAN DATA VAKSINASI SECARA TERKOMPUTERISASI
}

\author{
Gabriel Firsta Adnyana', Putu Wida Gunawan², Gerson Feoh ${ }^{3}$, I Made Dwi Ardiada ${ }^{4}$, I Nyoman \\ Bernadus $^{5}$, Prastyadi Wibawa Rahayu ${ }^{6}$
}

\author{
Universitas Dhyana Pura
}

gabrieladnyana89@undhirabali.ac.id'1 , putuwida@undhirabali.ac.id² ${ }^{2}$ gerson.feoh@undhirabali.ac.id ${ }^{3}$, dwiardiada@undhirabali.ac.id ${ }^{4}$, bernadus@undhirabali.ac.id ${ }^{5}$, prastyadiwibawa@undhirabali.ac.id ${ }^{6}$

\begin{abstract}
Abstrak
Satgas Covid-19 Yayasan Maha Bhoga Marga merupakan tim yang dibentuk dibawah koordinasi dari Bidang Pelayanan Kesehatan dan Pemberdayaan Masyarakat dibawah DEPLAPEM GKPB, dalam proses pendataan dan pelaporan vaksinasi Covid-19 terhadap warga jemaat GKPB masih belum sepenuhnya bisa dilakukan oleh Satgas Covid-19 Yayasan Maha Bhoga, oleh karena itu, melalui program kemitraan masyarakat, tim dari Program Studi Teknik Informatika Universitas Dhyana Pura memberikan pelatihan dan pendampingan dalam proses pelaporan, pendataan beserta penyampaian informasi seputar vaksinasi Covid-19 terhadap warga jemaat GKPB secara terkomputerisasi. Dalam langkah awal pelaksanaannya, Tim Satgas Covid-19 Yayasan Maha Bhoga Marga dibantu oleh beberapa mahasiswa dari Program Studi Teknik Informatika untuk melakukan sosialisasi dan pendampingan kepada Gereja-gereja di lingkungan GKPB seluruh Bali dalam hal proses pelaporan vaksinasi Covid-19. Proses pengolahan datanya didapatkan dengan menyebarkan kuesioner dengan media Google Formulir lalu proses pengolahan datanya menggunakan Database MySQL serta informasi seputar vaksinasi Covid-19 ditampilkan di website Yayasan MBM, sehingga dapat disimpulkan proses pelaporan dan pendataan vaksinasi Covid-19 secara terkomputerisasi secara umum sudah terlaksana dengan baik.
\end{abstract}

Kata Kunci: Covid-19, Pelaporan data Vaksinasi, Warga Gereja, Yayasan Maha Bhoga Marga

\section{PENDAHULUAN}

Yayasan Maha Bhoga Marga (MBM) adalah salah satu Yayasan yang bernaung di bawah Sinode GKPB yang berlokasi di daerah Kapal - Badung, Bali yang tujuannya adalah melakukan Pelayanan kelembagaan dan pemberdayaan ekonomi serta kesehatan masyarakat, selama Pandemi Covid-19 saat ini, Yayasan MBM khususnya Bidang Pelayanan dan Kesehatan berusaha untuk melakukan pelayanan dan penyuluhan kesehatan salah satunya adalah proses pendataan dan pelaporan data vaksin Jemaat GKPB, selama ini proses pelaporan dan pendataan vaksinasi masih belum mampu dilakukan karena belum adanya 
media yang bisa digunakan sebagai media pengolahan database. Salah satu upaya yang dilakukan kepada oleh satgas Covid-19 dari Yayasan Maha Boga Marga (MBM) kepada jemaat Gereja Kristen Protestan di Bali (GKPB) adalah melalui seminar-seminar yang dilakukan secara online. Untuk melengkapi program sosialiasi yang telah dilakukan, maka Program Studi Teknik Informatika Universitas Dhyana Pura bekerjasama dengan satgas Covid-19 MBM GKPB memberikan pendampingan dalam bentuk sosialisasi pengisian formulir dan pengolahan pelaporan data vaksinasi Covid-19 secara terkomputerisasi yang menunjukkan tindakan nyata yang harus dilakukan Jemaat GKPB dalam menerapkan protokol kesehatan dalam kegiatan sehari-hari. Selain itu, Pemerintah melalui Kementerian Kesehatan telah melakukan tindak lanjut dari protokol kesehatan yaitu vaksinasi dalam menghadapi pandemi Covid19. Sampai saat ini belum ada media dalam melakukan pendataan terhadap jemaat GKPB yang telah di vaksin. Berdasarkan hal tersebut, Program Studi Teknik Informatika Universitas Dhyana Pura memandang perlu memberikan penyuluhan dan pelatihan kepada tim satgas Covid-19 Yayasan MBM berupa 1) merancang sebuah formulir pelaporan vaksin, 2) melakukan kegiatan yang mencakup sosialisasi dan edukasi dalam proses pengisian form bagi warga, 3) melakukan edukasi dan sosialisasi penggunaan form dan database bagi tim satgas sebagai administrator 4) Membantu dalam proses perancangan konten website MBM mengenai informasi pelaporan vaksin bagi warga jemaat.

Program Studi Teknik Informatika Universitas Dhyana Pura memandang perlu mengambil bagian dalam pendampingan satgas Covid-19 MBM GKPB sebagai bagian dari Universitas dibawah naungan GKPB sekaligus juga memperkenalkan Program Studi Teknik Informatika Universitas Dhyana Pura dan memberikan kesempatan langsung kepada dosen dan mahasiswa dalam mengimplementasikan keilmuannya dalam proses pendampingan pelaporan dan pendataan proses Vaksinasi oleh tim Satgas Covid-19 Yayasan MBM kepada seluruh warga jemaat GKPB seluruh Bali serta manfaat yang didapatkan oleh Mitra pengabdian yaitu Yayasan MBM yaitu dapat mengolah database yang berisi informasi seputar proses pelaporan dan pendataan secara terkomputerisasi serta website yayasan MBM yang sudah ada saat ini bisa digunakan secara lebih informatif dalam menyajikan data riil berupa informasi prosentase warga jemaat yang sudah melakukan proses pelaporan vaksinasi dan juga kasus aktif jemaat yang terinfeksi Covid-19 di wilayah Sinode GKPB seluruh Bali.

\section{METODE}

Metode pelaksanaan pengabdian kepada masyarakat akan dilaksanakan dengan pendampingan secara langsung melibatkan mahasiswa dan dosen Program Studi Teknik Informatika Universitas Dhyana Pura. Adapun tahapan-tahapan yang dapat dijelaskan sebagai berikut:

1. Tahap Penentuan Target Kegiatan.

Pada tahap ini ditentukan target dari kegiatan penyuluhan dan pelatihan penggunaan teknologi terhadap proses pelaporan data vaksinasi Covid-19 bagi warga jemaat Gereja sesuai dengan data yang telah dipaparkan pada pendahuluan.

2. Tahap Perencanaan dan Penentuan Jadwal Penyuluhan dan Pelatihan

Setelah tahap penyebaran surat undangan, maka selanjutnya ditentukan jadwal daripelatihan, dimana rencana pelatihan dilakukan sebanyak 6 sesi yaitu pada hari hari kerja dengan jumlah pertemuan sebanyak 1 kali dalam seminggu dengan alokasi waktu selama $3 \mathrm{jam} / \mathrm{sesi}$.

3. Tahap Pelaksanaan Pendampingan

Pada tahap ini proses pendampingan dilakukan yang diawali dengan penyebaran kuisioner pra pendampingan. Pelaksanaan pendampingan awal dilaksanakan secara online dimulai dari proses mengisi daftar hadir oleh peserta pendampingan, proses perkenalan, proses penyampaian rencana pendampingan akan dilakukan oleh dosen-dosen di Program Studi Teknik Informatika. Pada Training ini juga dibantu oleh mahasiswa aktif Program Studi Teknik Informatika. 
4. Tahap Evaluasi Penyuluhan dan Pelatihan Pada tahap ini dilakukan proses evaluasi hasil dari penyuluhan dan pelatihan yang telah dilakukan. Proses evaluasi ini dilakukan di akhir pertemuan setiap sesi dalam bentuk kuisioner pasca target telah tercapai. Tujuan dari proses evaluasi ini adalah untuk mengetahui tingkat manfaat tim satgas Covid-19 yayasan MBM dan capaian yang didapatkan dalam proses penyuluhan ini.

5. Tahap Penyusunan Laporan akhir

Hasil akhir dari pelatihan seperti dokumentasi (foto pelaksanaan) dan hasil respon tim satgas Covid-19 yayasan MBM, dijadikan sebagai laporan akhir dari pelaksanaan kegiatan pengabdian.

\section{HASIL DAN PEMBAHASAN}

Kegiatan pendampingan pelaporan dan pengolahan data vaksinasi Covid-19 yayasan MBM bagi warga jemaat GKPB ini dilakukan selama 4 bulan mulai bulan Juni 2021 sampai dengan bulan Oktober 2021. Pelatihan dan pendampingan sudah terlaksana sesuai dengan perencanaan yang dibuat. Selama proses pelaksaannya telah dilakukan beberapa tahapan kegiatan sebagai berikut:

\section{Sosialisasi}

Pada tahap awal ini dilakukan sosialisasi kegiatan yang dihadiri oleh para dosen dan beberapa mahasiswa dari Program Studi S1 Teknik Informatika, Tim Satgas Covid-19, perwakilan dari Bidang Pelayanan Kesehatan dan Pemberdayaan Masyarakat dan juga Kepala Departemen Pelayanan dan Pemberdayaan Ekonomi jemaat (Yayasan MBM), tujuannya adalah untuk menjelaskan tahapan-tahapan kegiatan yang dilakukan selama proses pendampingan dan penyuluhan kegiatan pelaporan dan pengolahan data vaksinasi Covid-19 untuk warga jemaat GKPB seluruh Bali serta penyamaan persepsi antara dosen pengusul serta mitra dari kegiatan pengabdian ini. Sosialisasi ini dilakukan tanggal 4 Juni 2021 secara daring/online.

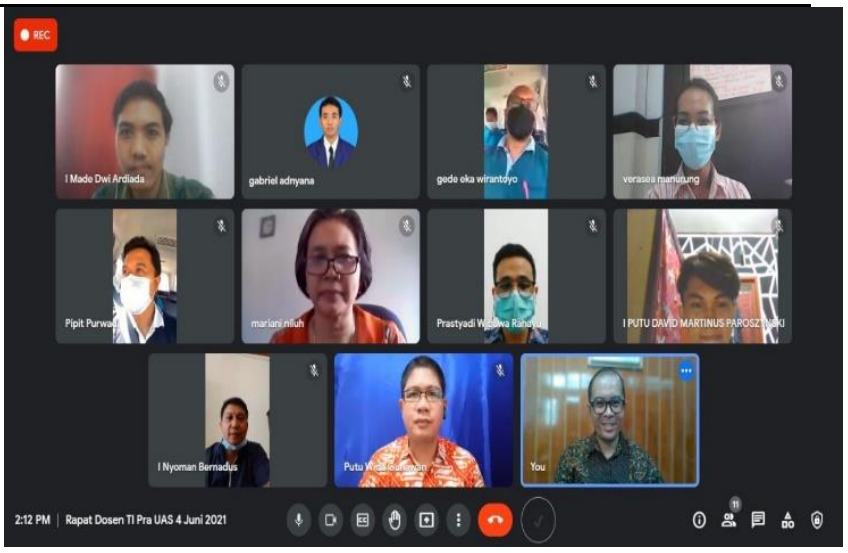

Gambar 1. Proses sosialisasi yang melibatkan mahasiswa dan para dosen Teknik Informatika Undhira kepada tim satgas Covid-19 yayasan MBM

\section{Tahapan Pembuatan Kuesioner}

Setelah melakukan proses sosialisasi kepada tim satgas Covid-19 yayasan MBM, maka proses selanjutnya adalah pembuatan kuesioner sebagai wadah pelaporan data vaksinasi kepada seluruh jemaat GKPB seluruh Bali. Adapun beberapa instrument yang dipakai dan menjadi patokan dalam pembuatan kuesioner yaitu; (1) kategori umur responden, (2) telah mendapatkan vaksin dosis pertama dan kedua, (3) pernah atau tidaknya terpapar Covid-19, (4) Sistem ibadah mingguan di masing-masing jemaat, (5) Orang dengan Kebutuhan Khusus (Cacat Mental dan Fisik) di Jemaat.

Proses pembuatan kuesioner dibuat dengan aplikasi Google Formulir dengan memanfaatkan aplikasi Microsoft Excel untuk menampung Database pelaporan yang didapatkan dari hasil pengisian kuesioner, untuk proses pengolahan data dari hasil kuesioner dilakukan dengan memanfaatkan aplikasi SQL Server untuk memudahkan administrator Tim Satgas Covid-19.

Untuk link dari formulir pelaporan data vaksinasi jemaat GKPB di Bali bisa dilihat pada link berikut ini https://bit.ly/3vaksinasigkpb-MBM 


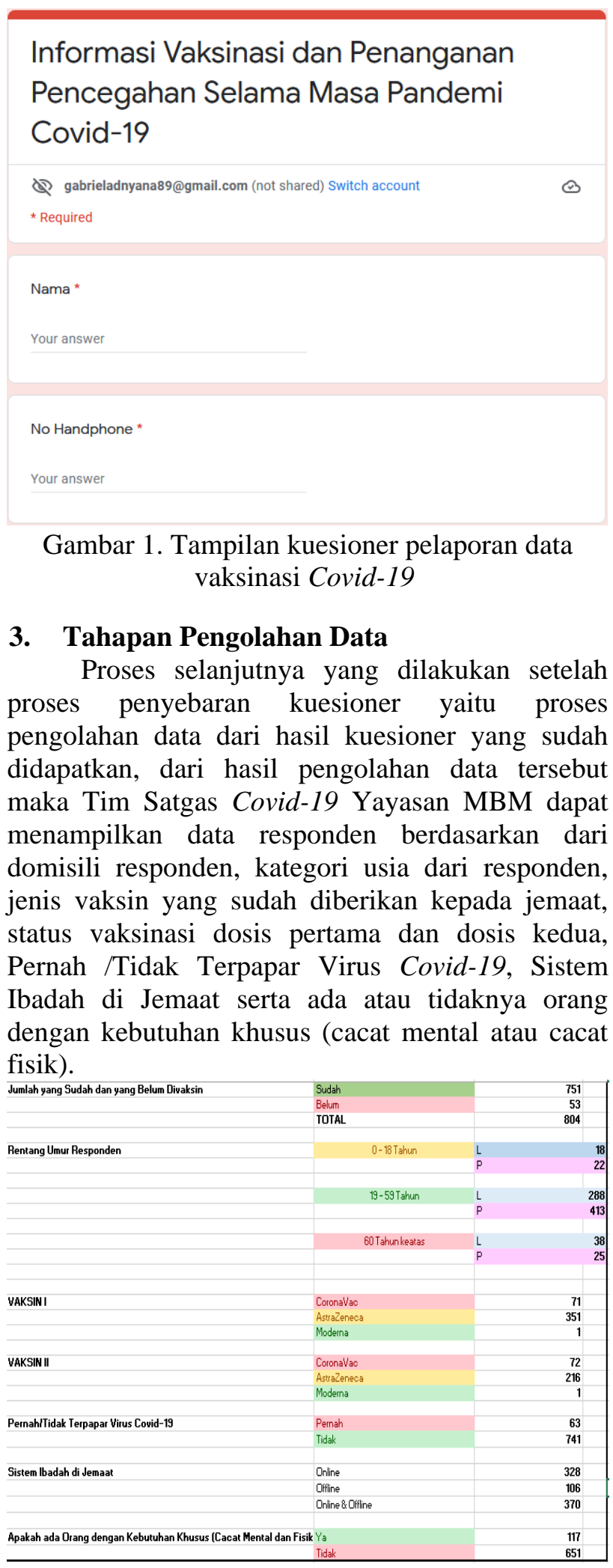

Gambar 3. Proses Rekapitulasi Pelaporan Data Vaksinasi Covid-19

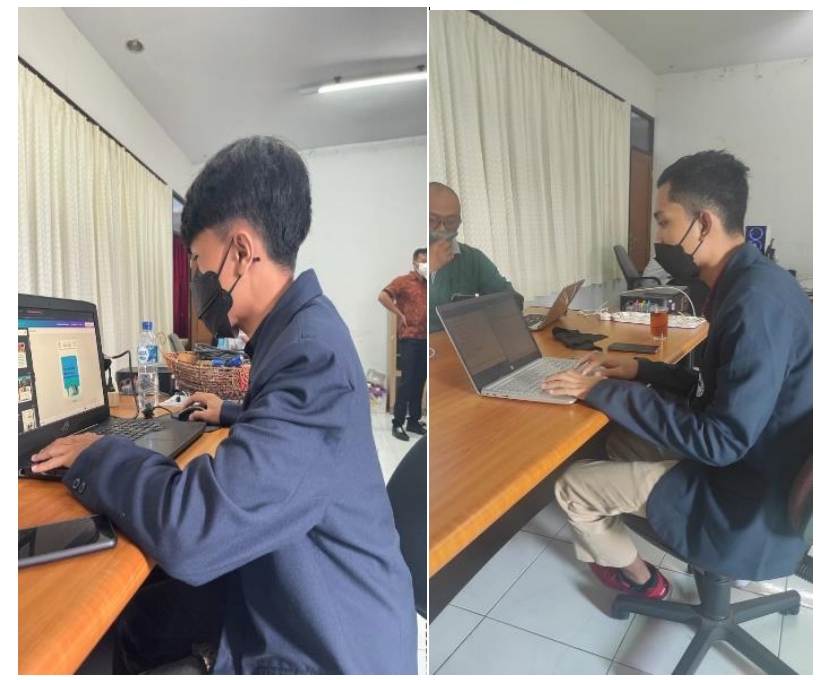

Gambar 4. Pendampingan oleh Mahasiswa Teknik Informatika dalam Proses Pengolahan Data Vaksinasi.

\section{Tahapan Integrasi Konten Website Terhadap Pelaporan Data Vaksinasi Covid- 19}

Pada tahapan selanjutnya adalah proses integrasi antara konten Website yayasan MBM terhadap proses pelaporan data vaksinasi Covid-19 yang berupa update data seputar warga jemaat GKPB yang terkonfirmasi Positive Covid-19 beserta update dari kasus aktif/sembuh/meninggal yang tercatat. Untuk website dari Yayasan MBM bisa dilihat pada link berikut https://mahabhogamarga.org/covid-19

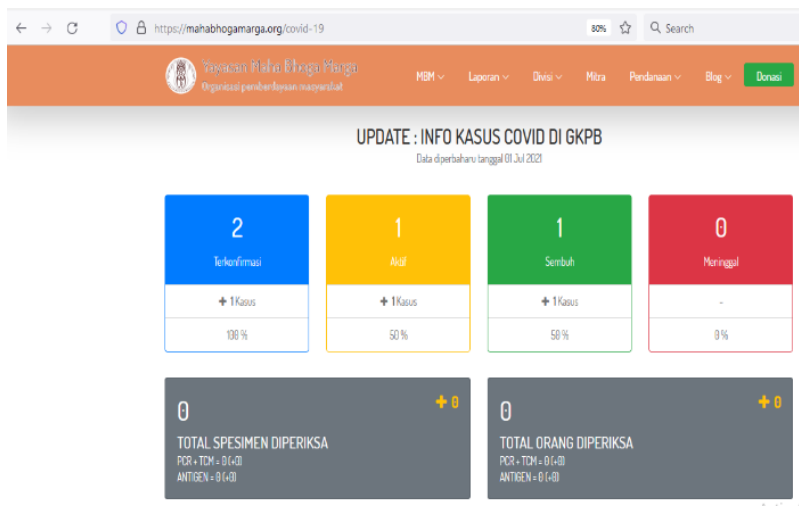


Gambar 5. Tampilan Website Yayasan MBM yang berupa informasi update seputar kasus Covid-19

\section{Tahap Penyusunan Laporan Akhir}

Pada proses ini merupakan tahapan akhir dari proses pendampingan oleh para Dosen Teknik Informatika terhadap Tim Satgas Covid-19 Yayasan MBM, pada proses penyusunan laporan akhir ini berdasarkan dari pengolahan data yang dilakukan maka didapatkan informasi sebagai berikut:

1. Total responden yang mengisi kuesioner sebanyak 804 responden yang terdiri dari 751 responden sudah mendapatkan vaksin Covid19 dan 53 responden belum mendapatkan vaksin Covid-19.

2. Rentang umur responden di bagi 3 kategori yaitu kategori anak-anak yaitu dengan rentang usia 0-18 tahun sebanyak 40 responden, kategori dewasa yaitu dengan rentang usia 1959 tahun sebanyak 701 responden, dan kategori lanjut usia yaitu dengan rentang usia 60 tahun keatas.

3. Proses vaksin tahap 1 berupa vaksin CoronaVac sebanyak 71 dosis, vaksin AstraZaneca sebanyak 351 dosis, dan vaksin Moderna sebanyak 1 dosis.

4. Proses vaksin tahap 2 berupa vaksin CoronaVac sebanyak 72 dosis, vaksin AstraZaneca sebanyak 216 dosis, dan vaksin Moderna sebanyak 1 dosis.

5. Warga jemaat yang pernah terpapar virus Covid-19 sebanyak 63 responden dan yang belum pernah terpapar virus Covid-19 sebanyak 741 responden.

6. Sistem ibadah mingguan di lingkungan GKPB seluruh Bali di masing-masing jemaat yang dilakukan secara online sebanyak 328 responden, dilakukan secara offline sebanyak 106 responden, dan dilakukan secara kombinasi online dan offline terhadap 370 responden.

7. Orang dengan kebutuhan khusus (cacat mental atau cacat fisik) di lingkungan GKPB seluruh Bali yang dilaporkan sebanyak 117 orang.

Berdasarkan hasil dari proses pengolahan data dan penyusunan laporan akhir dapat diketahui bahwa Tim Satgas Covid-19 bisa menampilkan informasi seputar jumlah, kategori usia warga jemaat yang sudah dan yang belum melaporkan proses vaksinasi Covid-19 dan juga jenis dari vaksin Covid-19 yang didapatkan. Hasil pengolahan data juga memberikan dampaknya sangat positif, dimana Website dari Yayasan MBM dapat lebih informatif yaitu dapat menampilkan informasi seputar proses pelaporan vaksinasi dan kasus aktif Covid-19 yang terjadi kepada warga jemaat GKPB. Potensi keberlanjutan dari program PKM ini akan dapat dilanjutkan sesuai kebutuhan dan perkembangan yang akan terjadi serta luaran-luaran yang dihasilkan mitra, sehingga dapat terus dilakukan monitoring secara berkala.

\section{KESIMPULAN}

Dari hasil pengolahan data kuesioner pelaporan data vaksinasi berbasis komputer yang dilakukan pendampingan oleh tim para dosen Teknik Informatika Universitas Dhyana Pura kepada Satgas Covid-19 Yayasan MBM dapat disimpulkan bahwa:

1. Proses pendampingan dan persiapan yang dilakukan antara para Dosen Teknik Informatika Universitas Dhyana Pura dan Tim Satgas Covid-19 Yayasan MBM telah berjalan dengan baik.

2. Proses pelaporan data vaksinasi Covid-19 jemaat yang telah di vaksin dan sinkroninasi update data yang ditampilkan pada website Yayasan MBM telah ditampilkan dengan baik.

Dari pelaksanaan kegiatan pengabdian kepada masyarakat tersebut masih ditemukan beberapa kendala yang perlu disempurnakan, oleh karena itu perlu diberikan arahan yang tepat kepada tim Satgas Covid-19 maupun pihak Yayasan MBM berikut ini:

1. Untuk proses sosialsiasi kepada masing-masing gereja di wilayah Sinode GKPB seluruh Bali dilakukan dengan pendampingan yang lebih intensif dan tahapan yang lebih jelas sehingga semua warga jemaat mampu memahami arah dan tujuan kegiatan ini.

2. Untuk proses penyusunan kuesioner kedepannya 
dapat dilakukan dengan menyusun instrumen pertanyaan yang sesuai dengan kaidah /metodemetode dalam proses pengambilan data sehingga tingkat keakurasian datanya tinggi.

\section{UCAPAN TERIMAKASIH}

Ucapan terimakasih disampaikan kepada Universitas Dhyana Pura melalui Lembaga Penelitian dan Pengabdian Masyarakat (LPPM) yang telah memfasilitasi dan memberikan kontribusi dalam pelaksanaan kegiatan Pengabdian kami dari Program Studi Teknik Informatika.

Ucapan terima kasih juga kami sampaikan kepada Bidang Pelayanan Kesehatan dan Pemberdayaan Masyarakat Yayasan Maha Bhoga Marga (MBM) khususnya Tim Satgas COVID-19 selaku mitra dari kegiatan pengabdian kami sehingga program pengabdian kami dapat berjalan dengan baik.

\section{REFERENSI}

Handarini, O. I. (2020). "Pembelajaran Daring Sebagai Upaya Study From Home (SFH) Selama Pandemi Covid 19.”. Jurnal Pendidikan Administrasi Perkantoran (JPAP) 8, no.3, 498.

Hesti Hasyim, R. R. (2020). Peranan Teknologi Informasi Dalam Upaya Pencegahan Virus COVID-19 di Lingkungan Universitas. . CIRCUIT (Jurnal Ilmiah Pendidikan Teknik Elektro), Vol.4,No.2,.

Latip, A. (2020). "Komunikasi Pada Pembelajaran Jarak Jauh Di Masa PandemiCOVID- 19.”. Edukasi Dan Teknologi 1, no. 2, 108-9.
Lubis, I. L. (Oktober 2020). Pemanfaatan Teknologi Informasi saat Pandemi Covid- 19. . Jurnal Prioritas : Jurnal Pengabdian Masyarakat, Volume : 02, Nomor : 02, 5.

Rubiani, H. S. (2021). SOSIALISASI SISTEM INFORMASI BERBASIS TEKNOLOGI INFORMASI SEBAGAI PENDUKUNG PENERAPAN PHYSICAL DISTANCING DI MASA PANDEMI COVID-19. BERNAS: Jurnal Pengabdian Kepada Masyarakat, 2(1), 309-316.

Saleh, M. (2020.). "Merdeka Belajar Di Tengah Pandemi Covid-19.". Prosiding Seminar Nasional Hardiknas., 51, http://proceedings.ideaspublishing.co.id/ind ex.php/hardiknas/article/view/8/8.

Shereen, M. A. (2020). Infeksi COVID-19: asal, penularan, dan karakteristik coronavirus manusia.". Jurnal Penelitian Lanjut.

Suni Astini, N. K. (2020). “Tantangan Dan Peluang Pemanfaatan Teknologi Informasi Dalam Pembelajaran Online Masa Covid-19.". Cetta: Jurnal Ilmu Pendidikan 3, no. 2 , 243. https://doi.org/10.37329/cetta.v3i2.452.

Syafrida, S. (2020). Bersama Melawan Virus Covid 19 di Indonesia. SALAM: Jurnal Sosial dan Budaya Syar-i 7, 6. 